\title{
The Positive Relationship between Teaching or Using English Poetry as an Instructional Source and the Teaching - Learning of Different Language Skills and Sub Skills
}

\author{
Abd-Al-Hameed Mustafa Jabsheh ${ }^{*}$ \\ Department of Languages, Palestine Technical University Kadoorie (PTUK)
}

DOI: $10.36348 /$ sjhss.2019.v04i11.007

| Received: 16.11.2019 | Accepted: 23.11.2019 | Published: 29.11.2019

*Corresponding author: Abd-Al-Hameed Mustafa Jabsheh

Abstract

The aim of this study was to investigate, in a descriptive, argumentative and chronological methodology, about the positive relationship between teaching or using English poetry as an instructional source and the teaching-learning of different language skills such as reading, listening, speaking, and writing as well as other language sub skills such as pronunciation, grammar, structure, and vocabulary. Accordingly, this study is oriented towards answering the following two questions: 1. Is there any positive relationship between teaching or using English poetry as an instructional source and the teaching-learning of different language skills such as reading, listening, speaking, and writing as well as other language sub skills such as pronunciation, grammar, structure, and vocabulary? 2. What is the status of teaching or using English poetry as an instructional source in ELT? To achieve the purpose of this study, the researcher carried out a panoramic chronological review of some of the findings of previous related literature in order to draw an explanatory and argumentative line of understanding in regard to the aim and questions of this study. Findings of this study indicate that poetry can gain an effective place, as a reliable and adaptable source, in the language teaching methodology and ELT classroom. Findings of this study, in accordance with previous literature, also indicate that the teaching or using English poetry, as an instructional source for the teaching and learning English language skills and sub skills, is either neglected or avoided by teachers and students of both native and foreign settings. Conclusions of this study, based on previous literature and findings of this study, indicate that a positive relationship between teaching or using English poetry as an instructional source and the teaching-learning of different language skills such as reading, listening, speaking, and writing as well as other language sub skills such as pronunciation, grammar, structure, and vocabulary, is existent and clearly asserted and vouched for. The researcher recommends carrying out further studies to investigate about the reasons of why the teaching or using English poetry as an instructional source for the teaching and learning language skills and sub skills is neglected or avoided in both foreign and native settings, and to separately investigate about the effect of using English poetry as a source on the teaching and learning of each of the language skills and sub skills.

Keywords: English poetry, ELT, Language skills, Language sub skills, Instructional source, Foreign setting, Native setting.

Copyright @ 2019: This is an open-access article distributed under the terms of the Creative Commons Attribution license which permits unrestricted use, distribution, and reproduction in any medium for non-commercial use (NonCommercial, or CC-BY-NC) provided the original author and source are credited.

\section{INTRODUCTION AND BACKGROUND}

Depending on previous related literature in the field, it can be stated that the teaching - learning of language skills such as listening, reading, speaking and writing, and other sub skills such as pronunciation, grammar, structure, and vocabulary, through literature in general and poetry in particular, has been a debatable area among pros and cons; on the one hand, previous literature acknowledged the existence of a positive relationship between teaching or using English poetry as a reliable, adaptable, and an apt instructional source for the teaching - learning of the English language skills and sub skills; but on the other hand, and in regard to the status of teaching and using English poetry as a source for the teaching- learning of language skills and sub skills, findings of some previous literature concluded that the teaching and learning of poetry is either neglected or avoided by teachers and students of both native and foreign settings; furthermore, some other previous related literature in the field has asserted that the teaching or using English poetry, as an instructional source, for the teaching - learning English language skills and sub skills, has a logical place in ELT that is so rewarding and vastly exploitable. 
Accordingly, the aim of this study was to investigate, in a descriptive, argumentative and chronological methodology, about the positive relationship between teaching or using English poetry as an instructional source and the teaching- learning of language skills such as reading, listening, speaking, and writing as well as other language sub skills such as pronunciation, grammar, structure, and vocabulary. To achieve the purpose of this study and to answer its questions, the researcher followed an investigative, a descriptive, an argumentative and a chronological methodology through previous and available related literature. The significance of this study is stemmed from the fact that it can orient the attention of English teachers and educators towards the importance of teaching or using English poetry as an instructional source for the teaching - learning different language skills and sub skills, and by the same token, suggests an advantageous and exploitable ELT approach. Another aspect of the significance of this study is that it can establish an explanatory rationale that motivates teachers, educators, and students to adopt English poetry as an instructional source for the teaching-learning of language skills and sub skill instead of neglecting or avoiding that rich resource. One limitation of this study is that it does not investigate about the positive relationship between all literary genres and the teaching-learning of language skills and sub skills, rather is confined to poetry only; a second limitation of this study is that it does not investigate about the reasons or the rationale supporting the point of views of either the pros or cons in regard to using or neglecting poetry as an instructional source for teaching- learning language skills and sub skills. In addition, it is beyond the aim and the questions of this study to investigate about the reasons nor the rationale of why poetry is neglected or avoided in both native and foreign setting.

\section{REVIEW OF RELATED LITERATURE}

In accordance with the aim, rationale, and questions of this study, the following literature review will be divided into three main parts: The first part of this review presents an overview of the available studies describing the status of using or teaching English poetry as an instructional source for the teaching-learning of language skills, which is found out, in conclusion, to be avoided or to some extent disregarded: for example, Gönen, S. İ. K [1], indicated that "Poetry has often been neglected as a favorable tool for language teaching." and accordingly, "its role to expand human experience and create language awareness has not been fully realized." Roebuck, C. D [2], concluded that "poetry as an instructional text, as a means towards helping students gain effective reading and writing skills, and as a text that can be enjoyed and savored if introduced effectively, is disappearing." Tevdovska, E. S [3], concluded that" poetry is regarded by most ESL/EFL learners, as well as teachers as complex and too difficult therefore contributing very little to second language learning and the development the of language skills."
Ardeshir, D., \& Shirkhani, S [4] stated that "there has been a return to the integration of literature, including poetry, into the language teaching practice while even now there are people opposing the use of literature in language teaching." Mittal [5], concluded that "Poetry was not considered apt and appropriate for second language learning especially when we talk about Grammar, communication skills etc." Çetinavcı and Tütüniş [6], cited in Safiye İpek Kuru Gönen [1], concluded that "lack of training on using literature as part of language teaching methodology creates a tendency to underestimate the role of poetry in EFL/ESL teaching contexts." Anstas [7], concluded that "teaching English poetry in a foreign language setting is neglected and to some extent hated by the students." Andrews [8], stated that "poetry suffers as perhaps the "highest" literary form, from attitudes that extol the "realistic" at the expense of fictional." Akyel and Yalcin [9], cited in Ardeshir, D., \& Shirkhani, S [4], found that "students view poetry as not having much effect on language skills and making the least significant contribution to the development of language skills among literary genres." Maley, A., \& Duff, A [10], cited in Reppert, K. R [11]. Stated that "for many years now literature and in particular poetry has not been regarded as 'proper' material for foreign language learning .... the utilitarian bias of the communicative approach deflected attention away from anything which did not seem to have a practical purpose."

The second part of this literature review presents an antithetical account to the previous part of this literature review which was centered, as mentioned above, on the idea of neglecting or avoiding the use of poetry as reliable source for language teaching and learning; the following review of related studies establishes a valid account of the place of poetry, as a reliable and adaptable source, in the language teaching methodology and ELT classroom. Gönen, S. İ. K [1], stated that "poetry can have a place in language teaching by using a systematic and guided framework tailored to the features of a language classroom." Gönen, S. İ. K [1], then concluded that "poetry can become part of language teaching methodology." Ardeshir, D., \& Shirkhani, S [4], found out that "a considerable percent of the students believe that English poetry helps in the development of various aspects of the foreign language." Ardeshir, D., \& Shirkhani, S [4], also added that that "Literary materials, in general, and poetry, in particular, can be used as effective sources of authentic materials in language teaching classrooms." Thakarar, G [12], stated that "Teaching language through poetry can prove quite effective for the teaching and learning of basic language skills." Hanauer [13]; Maley and Duff [10], cited in Kellem, H [14], stated that "different researchers have reported, including poetry-based activities in the EFL classroom is beneficial." Atay [15] cited in Özen, Mohammadzadeh [16], found that "the language awareness and critical thinking skills of the students 
were affected positively with the help of analyzing poetry." Agustín Llach, P [17], Cited in Antika [18] stated that "Poems become favorite tools for language teachers due to their short length, perfectly suitable for a single classroom lesson, their peculiar structure, and their linguistic characteristic features" and added that "The evocative character of poetry, its imagery, its appeal to feelings and personal experience make it very interesting and enjoyable for the second/foreign language learners." Duff and Maley [19], Cited in Gönen, S. İ. K [1], asserted that "poetry provides a rich source for language input." Özal [20], cited in [16], concluded that "poetry-based instruction created a positive effect on the students' attitude towards foreign language learning." Andrew Finch [21] suggested that "a broader perspective on the use of poetry in the language classroom can lead to meaningful and successful language learning." M. Amirullah Khan [22] argues that "using poetry in classroom provides students with an increased awareness and understanding of English speaking cultures in addition to a great sensual, emotional, and intellectual pleasure."

The third part of this literature review presents an overview of the available studies that have established evidence of the usefulness, credibility, adaptability, and suitability of teaching or using English poetry and the teaching- learning of different language skills such as listening, reading, speaking, and writing, and sub skills such as vocabulary, grammar, structure, comprehension, and pronunciation: Özen, Mohammadzadeh [16], asserted that "it is possible to use poetry-based vocabulary teaching activities instead of vocabulary activities in the course books used in the EFL classrooms.", Bass-Nelson [23], concluded that " the use of phonology, alliteration, and rhyme in poetry can facilitate early reading ability." Lazar [24], cited in Gönen, S. İ. K [1], indicated that "Using poems in the language classroom have many reported benefits from both linguistic and literary perspectives." and that "numerous linguistic gains can be counted such as poems' potential to enrich vocabulary." Bush [25], concluded that "Poetry can be used in various ways to enhance vocabulary development, to encourage more creative and fresh phrasing in student compositions." Dwyer [26], cited in Bush [25], found a relationship between "studying poetry and vocabulary development as well as comprehension development." Kellem, H [14], Asserted that " poetry is a source of content-rich reading material; a model of creative language in use; a way to introduce vocabulary in context; and a way to focus students' attention on English pronunciation, rhythm, and stress." Honeyghan [27] asserted that there is evidence "linking various facets of poetry and literacy development; for example, poetry being central in promoting basic language art skills--listening, speaking, reading, and writing." Edelman [28], demonstrated that "listening, speaking, reading and writing can be built around the study of poetry." Tosta [29], argues that "poems can be used for "warming up", reading exercises, listening activities, grammar presentations or practice, and finally for practicing pronunciation and writing." Gültekin [30], cited in Özen, Mohammadzadeh [16], studied the positive impact of using poetry on speaking skills, and concluded that "using poetry in speaking courses was useful because it created meaningful situations for the learners to be able to communicate with each other in a 2nd language." Raymond [31] described "a literaturebased and a first-year composition course that allows students to read poetry and understand it, which in turn helps them to become better writers." Moran, M. G [32]. In this course, students read a few seminal texts of a few seminal authors or essays, poetry or drama; discussed the ideas of those texts thoroughly in class; and wrote essays about the views of life expressed in these works. Ramsaran [33], cited in M Alabi, A [34], stated that "The imperativeness of poetry in language teaching class is that it is distinctively different from other literary work of art; it breaks some grammatical rules in language usage." Kırkgöz, Y [35], cited in Gönen, S. İ. K [1], reported that using poems in language teaching "improve pronunciation, foster grammatical knowledge." Mittal, R [5] found out that the "Use of grammar is not easy for Non English background students but they too can exercise it will in poetry." Khansir [36], Cited in Antika [18] concluded that "Poetry as one of the literature products can be used to develop learners' knowledge of English and to teach structure, grammar and vocabulary." Ardeshir, D., \& Shirkhani, S [4] concluded that out of the population of the study" 54 percent agreed that poetry helps the development of vocabulary, 32 percent agreed that poetry can lead to the development of grammar, 46 percent agreed that poetry is helpful in developing reading comprehension, and 35 percent agreed that poetry can result in the development of writing ability."

To sum up, the above mentioned literature review presented three domains dealing with the central argument exhibited by the aim and questions of this study: the first domain represents a demonstrative account of the status of teaching or using English poetry which is found, in conclusion, to be neglected and avoided by teachers and students in both native and foreign settings; the second domain establishes a valid account of the place of poetry in teaching-learning language in general; the third and last domain provided evidence of the positive relationship between teaching or using English poetry as an instructional source for the teaching- learning English language skills such as reading, listening, speaking, and writing as well as other language sub skills such as pronunciation, grammar, structure, and vocabulary.

\section{FINDINGS AND CONCLUSIONS}

Depending on the previous presentation of related literature and in accordance with the aim and questions of this study, it can be concluded that a positive relationship between teaching or using English 
poetry as an instructional source and the teachinglearning of different language skills such as reading, listening, speaking, and writing, as well as other language sub skills such as pronunciation, grammar, structure, and vocabulary, is existent and clearly asserted and vouched for, even though the findings of this study, depending on some of the related literature, indicated that the teaching or using English poetry, as an instructional source for the teaching and learning English language skills and sub skills, is either neglected or avoided by teachers and students of both native and foreign settings. Furthermore, the findings of this study indicated that the teaching or using English poetry, as an instructional source, for the teaching learning English language skills and sub skills, has a logical place which can be rewarding, beneficial, advantageous and exploitable.

\section{RECOMMENDATIONS}

Based on the findings and conclusions of this study, the researcher recommends carrying out further studies to investigate about the reasons of why the teaching or using English poetry as an instructional source for the teaching - learning language skills and sub skills is neglected or avoided in both foreign and native settings. Depending on the fact, which is asserted by previous literature, that a positive relationship between teaching or using English poetry as an instructional source and the teaching-learning of different language skills such as reading, listening, speaking, and writing, as well as other language sub skills such as pronunciation, grammar, structure, and vocabulary, the researcher also recommends carrying out further studies investigating, in a separate manner, about the effect of teaching or using English poetry as an instructional source on the teaching and learning of each language skill and sub skill.

\section{REFERENCES}

1. Gönen, S. İ. K. (2018). Implementing Poetry in the Language Class: A Poetry-Teaching Framework for Prospective English Language Teachers. Advances in Language and Literary Studies, 9(5), 28-42.

2. Roebuck, C. D. (2015). Impact and import of poetry in high school pedagogy: a study of practice and student learning (Doctoral dissertation, Rutgers University-Graduate School-New Brunswick).

3. Tevdovska, E. S. (2016). Literature in ELT Setting: Students Attitudes and Preferences towards Literary Texts. Procedia-Social and Behavioral Sciences, 232, 161-169.

4. Ardeshir, D., \& Shirkhani, S. (2015). Students' Attitudes towards the Use of Poetry in Second Language Classrooms. Journal on English Language Teaching, 5(2), 28-33.

5. Mittal, R. (2014). Teaching English through poetry: A powerful medium for learning second language. IOSR Journal of Humanities and Social Science, 19(5), 21-23.

6. Çetinavcı, U. R., \& Tütüniş, B. (2012). Making use of poems to teach English. The Journal of Language Learning and Teaching, 2(2), 75-88.

7. Anastas, H. (1992). The Influence of Teaching English Literature on Learning English As A Foreign Language, Unpublished dissertation, AnNajah National University, Nablus.

8. Andrews, R. (1991). The Problem with Poetry. Britain: Open University Press

9. Akyel, A., \& Yalcin, E. (1990). Literature in the EFL class: A study of goal-achievement incongruence. ELT journal, 44(3), 174-180.

10. Maley, A., \& Duff, A. (1989). The inward ear: Poetry in the language classroom. Cambridge University Press, 40 West 20th St., New York, NY 10011.

11. Reppert, K. R. (2004). Literature and the development of oral fluency: a study using poetry and children's literature in adult ESL instruction.

12. Thakarar, G. (2015). Literature in EFL/ESL classroom: a multifaceted practice in ELT. Research Scholar, 3(1), 414-421.

13. Hanauer, D. I. (2001). The task of poetry reading and second language learning. Applied linguistics, 22(3), 295-323.

14. Kellem, H. (2009). The Formeaning Response Approach: Poetry in the EFL Classroom. In English Teaching Forum; 47(4):12-17. US Department of State. Bureau of Educational and Cultural Affairs, Office of English Language Programs, SA-5, 2200 C Street NW 4th Floor, Washington, DC 20037.

15. Atay, Ö. (2007). Poetry in primary school EFL classroom: A language based approach. Unpublished MA Thesis, Çukurova Üniversitesi, Sosyal Bilimler Üniversitesi, Adana.

16. Özen, B., \& Mohammadzadeh, B. (2012). Teaching vocabulary through poetry in an efl classroom. International Online Journal of Primary Education (IOJPE), 1(1).

17. Agustín, L. P. (2007). Teaching language through literature: The waste land in the ESL classroom.

18. Antika, R. (2012). Efektivitas Drama dalam Meningkatkan Kepercayaan Diri pada Anak Prasekolah.

19. Duff, A., \& Maley, A. (2007). Literature (Second Edition), Oxford University Press, Oxford.

20. Özal, D. (2006). The Use of Poetry to Teach English in Intermediate Level for EFL Students. Samsun: Ondokuz Mayıs Üniversitesi, Sosyal Bilimler Enstitüsü, MA Thesis.

21. Andrew, F. (2003). Using Poems to Teach English, English Language Teaching.

22. M. Amerullah, K. (1993). Poetry in the Adult Literacy. English Teaching Forum, 31, 4.

23. Bass-Nelson, E. (1991). Enriching and Increasing Kindergarteners' Knowledge, Ability to Recite, 
Write, and Appreciate Poetry Integrated across a Standardized Curriculum.

24. Lazar, G. (1996). Literature and language teaching; exploring literary texts with the language learner. Tesol Quarterly, 30(4), 773-776.

25. Bush Jr, H. K. (1993). Poetry and the Teaching of Figurative Language Skills.

26. Dwyer, E. J. (1982). Guided reading in poetry: combining aesthetic appreciation and development of essential skills. Reading Psychology: An International Quarterly, 3(3), 261-264.

27. Honeyghan, G. A. (1996). Poetry as instructional text in an urban community college developmental reading and writing course.

28. Edelman, M. (1985). Teaching Literature Grade 9: Integrating the Communication Arts. Poetry. Experimental. [S.1.]: Distributed by ERIC Clearinghouse.

29. Tosta. (1996). Poetry? It's Worth A Try. English Teaching Forum, July/ October 1996.

30. Gültekin, S. (2006). Using poetry in EFL speaking classes - a classroom based study. Ankara: Bilkent -niversitesi, Sosyal Bilimler Enstitüsü, MA Thesis.
31. Raymond, R. (1994). Seeing, Hearing, and Knowing: From Poetry to Prose in Comp 102. Teaching English in the Two-Year College, 21(1), 33-41.

32. Moran, M. G. (1995). Frank Aydelotte and the Oxford Method of Teaching Writing in America.

33. Ramsaran, S. (1983). Poetry in the language classroom. ELT Journal, 37(1), 36-43.

34. M Alabi, A. (2015). Teaching vocabulary through poetry in an EFL classroom. International Journal of New Trends in Arts, Sports \& Science Education (IJTASE), 4(4).

35. Kırkgöz, Y. (2008). Using poetry as a model for creating English poems. Journal of Language and Linguistic Studies, 4(2): 94-106.

36. Khansir, A. A. (2012). Teaching Poetry in the ELT Classroom. International Review of Social Sciences and Humanities, 3(1). Retrieved at http://irssh.com/yahoo_site_admin/assets/docs/24_I RSSH-288 V3N1.131231639.pdf on June 10, 2013. 